\title{
Popularizing Haute Couture: A Balenciaga Brand Case Study
}

\author{
Leonardo Jacques Gammal Zeitune ${ }^{1,2}$ (]) \\ ${ }^{1}$ University of Lisbon, Lisbon, Portugal \\ ${ }^{2}$ Masters in Creative Economy Management from Escola Superior de Propaganda e Marketing do Rio de Janeiro and Research, \\ Associate of the Creative Cities Laboratory, Rio de Janeiro, Brazil \\ Email: lzeitune94@gmail.com
}

How to cite this paper: Zeitune, L. J. G. (2021). Popularizing Haute Couture: A Balenciaga Brand Case Study. Art and Design Review, 9, 46-57.

https://doi.org/10.4236/adr.2021.91004

Received: January 14, 2021

Accepted: February 5, 2021

Published: February 8, 2021

Copyright (c) 2021 by author(s) and Scientific Research Publishing Inc. This work is licensed under the Creative Commons Attribution International License (CC BY 4.0).

http://creativecommons.org/licenses/by/4.0/ (c) (i) Open Access

\begin{abstract}
Technology has transformed the way big names of the fashion industry release their collections and exhibitions. From Youtube to Instagram, products of the new technological revolution, even luxury brands have approached their audience by using mass communication. That having been said, the main objective of this article is to introduce the concepts of popular culture and mass culture in order to relate them with haute couture through a case study of Balenciaga brand, which is originally a product of haute couture and nowadays has redesigned their clothes from a creative element conquering its audience in social media.
\end{abstract}

\section{Keywords}

Popular Culture, Mass Culture, Balenciaga, Haute Couture, Instagram

\section{Introduction}

In the last few years, the world faced a big transformation in the technology sector, in particular the technologies of communication and reproduction. The field of arts and culture in general has been revolutionized by the mass media production, otherwise nowadays we could not think of culture without technological revolution, that is, without film, radio, television and portable devices. Due to the dissemination of mass media, several authors coined the term "mass culture" in order to make an apology to the concept of popular culture.

According to Hobsbawm (2000: p. 121), "there has always been a tendency for elites from each nation to share a 'world' or 'global' culture." In the late 1940's, T.S. Eliot had already affirmed, "it is an essential condition of the preservation of the quality of the culture of the minority, that it should continue to be a minority 
culture." (Eliot, 1948: p. 105). He claimed his belief in the potential of a minority elite to preserve the quality of culture (high culture) from the dangers of emergent massification. However, the spread of the Internet during the end of the twentieth century, further increased by more recent technological developments, created a process of globalization and of getting cultures to conform with each other, which the author called as "mass popular culture". Therefore, we cannot speak of popular culture without taking into consideration the concept of high culture.

The study of popular culture began with the work of Matthew Arnold in his main work "Culture and Anarchy". For Arnold, culture is a body of knowledge, "the best that has been thought and said in the world". That is to say, high standards and values of culture belong to an educated minority. In short, culture would remove popular culture, which was embodied in the male urban working class from the Second Industrial Revolution, also known as the Technological Revolution. The same thought is shared by F.R. Leavis, who argues that before the industrialization and standardization period brought by the industrial revolution, England had a vigorous common culture, a culture of the educated minority. However, during the late nineteenth and early twentieth century, this common culture was fragmented into two cultures: on the one hand, a minority culture; on the other, a mass civilization.

Since the approach of this article will rely on the fashion industry (to be later and further discussed), it is important to highlight that following Arnold and Leavis ideas of culture art and fashion were separated into two different cultural spheres in line with a more general division of arts and crafts in European society during the nineteenth century. This separation was greatly influenced by the idea that art would lose its higher status in society whereas fashion was considered a mere entertainment. As philosopher Lars Fr. H. Svendsen (2006) has noticed in his book "Fashion: A Philosophy" "the relationship between fashion and art is asymmetrical because fashion persistently has courted the world of art, whereas the artistic interest in fashion historically has been less tenacious." In other words, parts of the art world have feared that a strong relation to fashion potentially would entail that art permanently lost its higher status in society.

Throughout the twentieth century, surrealist, Dadaist and pop artists challenged general conventions of art by introducing everyday objects, including fashion items, into the institutional context of the museum and gallery. Andy Warhol displayed celebrity images of fashion icon Marilyn Monroe in the 1960s, and artist Meret Opppenheim "served" a pair of white pumps on a silver plate in her work "Ma Gouvernante" from 1936. As per Hobsbawm (2013: p. 18), the idea of mixing different elements in order to modernize art simply does not apply to the world of sensory impressions and feelings that we are currently living in. The author argues that this inundation of feelings prevents us to analyze personal artistic creations from a disconnected series, that is, creativity no longer means a prestige, which carries the name of the designers.

Haute Couture is today no longer understood as the playground of brilliant 
individual creators. The big names of the fashion industry were dominated by the fashion of the masses (Hobsbawm, 2013: p. 18). A great example is Balenciaga, a luxury brand, which was founded by the couturier Cristobal Balenciaga and today use mass media to communicate and exhibit their collections. The brand will be the case study of this article as it provides a real example of an articulation between the concepts presented above.

\section{Popular Culture and "Mass Culture"}

According to John Storey (1997: p. 23), popular culture is never actually defined. However, it becomes clear through Arnold's work ("Culture and Anarchy") that the term "anarchy" operates in part as a synonym for popular culture. Against such "anarchy" there is culture as the idea of the State, in order to maintain the aristocracy as the centre of authority.

Arnold's main concern is not culture but to maintain social authority. He believes that education would bring to the working class a "culture" and remove their temptations for cheap entertainment and social disorder. In short, culture would remove popular culture.

The work of Arnold was a key to influence other icons of the culture studies, namely Frank Raymond "F.R." Leavis and Queenie Dorothy "Q.D." Leavis. Their work takes Arnold's idea of culture as the high point of civilization and applies to the "cultural crisis" of 1930s, spanning for four decades. Leavisism, as it became known, had identified that Arnold's idea of cultural decline in the nineteenth century significantly increased in the twentieth century with the arise of the industrialization.

F.R Leavis argued that prior to the Industrial Revolution, England had an authentic common culture of an educated minority elite which has been lost due to the "standardization and levelling down" of the industrialized mass culture. (Leavis \& Thompson, 1933: p. 3) That is, the common culture fragmented into two cultures: on the one hand, a minority culture; on the other, a mass civilization. This consisted of mass culture, commercial culture consumed by the "uneducated" majority. (Storey, 1997: p. 30).

For some cultural critics working within mass culture paradigma, mass culture is not just an imposed and impoverished culture, but an identifiable sense of an imported American culture. Fiedler (1955) claims that mass culture is a peculiarly American phenomenon, however it is not only found in United States, but wherever it is found, it comes first from us as individuals. As far as Shils (1978) can see, the problem is not mass culture, but the response of intellectuals to mass culture. It is another notion of cultural consumption as an automatic and passive activity.

According to Macdonald (1953: p. 30), mass culture undermines the vitality of high culture. It is a parasitic culture, feeding on high culture, while offering nothing in return." The same idea is followed by Van Den Haag (1963, p. 235) as he says that "mass culture moves towards an endlessly cycle of a continuum non-fulfilment, boredom and distraction. It impoverishes life without leading to 
contentment." Although both authors criticize mass culture as impoverished and the origin of high culture deterioration, Haag agrees that it has become important for cultural producers in Western societies. The author says we must take two temptations offered by mass culture to high culture into consideration: the financial rewards of mass culture and the potentially enormous audience (Van Den Haag, 1963: p. 512). The causes are partly technological and partly economic.

The mass consumer society is unthinkable without technological revolution (Hobsbawm, 2013: p. 9). The author states that this century's inventions such as technologies of communication and reproduction, for example: films, radio, television, portable devices were significant to the process of getting cultures to conform with each other and spread a global "mass popular culture", as there has always been a tendency for elites from each nation to share a "world" or "global" culture (Hobsbawm, 2000: p. 121).

Then, there is the economic aspect, which has made rapid communication possible upon the growth of a global market. According to Hobsbawm (2000: p. 122), there is nothing that illustrates globalization better than football as it was transformed in a genuine global and international entertainment (it can be transmitted to the entire world at the same time). Leaving sport aside, standardization is characteristic of the modern mass culture; high culture does not share this propelling force. Literature cannot be standardized because of a very powerful language limitation. We need a global language, a global culture.

High culture cannot be only for insignificant elite (in terms of culture). Nowadays, English is the global language and when it comes to literature, specialists have already been developed technologies in order to facilitate the spread of high standard literary studies to the world. The same thing occurred within the arts and fashion industry.

Williams's concept of culture is rather anthropological than based on arts and literature. However, according to Chris Barker \& Emma Jane (2016: p. 47), "culture is the arts and the values, norms and symbolic goods of everyday life. While culture is concerned with tradition and social reproduction, it is also a matter of creativity and change." The authors stress that culture is a set of norms and behaviors of everyday life, a culture that refers to the ordinary process of making meaning from the various ways we interpret the world.

Hobsbawm (2013) does not agree with Williams' (1975) idea of culture as ordinary in every mind and every society. To mean that arts and learning are the processes of discovery and creative effort is to say that every individual can do art. That is, art is no longer what I can do and produce creatively, but what I am thinking (Hobsbawm, 2013: p. 17). The author call it "conceptual art" in order to make a contrast with "fine art". While the former is based on the idea of "ready-made art", the latter is based on the creativity of a single artist.

Art as well as fashion has a creative element, but today it cannot be considered more than a routine work. The big names of fashion have become mere enter- 
tainment for the global firms commercial of an adornment for the human body. As Hobsbawm (2013: p. 18) states:

"Haute couture is no longer understood as the playground of brilliant individual creators, of a Balenciaga, a Dior, a Gianni Versace, whose great works, commissioned as one-off pieces by rich patrons, inspires and thus dominate the fashion of the masses"

Today, the fashion industry, more specifically the luxury goods segment, has the digital media as the focus of their communication process. The digital technology delivers efficiency and accurate segmentation. It is the most efficient way to be part of conversation, and mainly, to guide the conversation between consumers.

With the decrease in investment in traditional media, mainly in print media, the digital assumed the role of investments mainly from brands with a public niche, like the luxury fashion segment (especially haute couture).

In this movement of migration to digital, which are constantly happening in the fashion world, it is important to highlight the Balenciaga's communicational construction on social media. The role that Balenciaga takes on social media and its communicational construction are worthy of an in-depth analysis, as it is a case that best represents this movement within the world of luxury fashion.

\section{A Brief Explanation of Haute Couture}

Haute Couture's prestige is shared through the diversity of affordable products that carry the name of designers, and are thereby invested with the high symbolic value of couture, which thus reaches a mass market (Bourdieu, 1975: p. 21). On the other hand, Douglas and Isherwood (1996: p. 51) define Haute Couture as "the enjoyment of the sharing of names", which turns into a pleasurable experience of fashion. "(...) enjoyment of physical consumption is only a part of the service yielded by goods: the other part is the enjoyment of sharing names." In the same way that material production is only one aspect of the production of cultural artefacts, material consumption is only one aspect of the consumption process. The other aspect is the symbolic consumption of goods. Whereas Douglas and Isherwood (1996) emphasize the enjoyment provided by symbolic consumption, Bourdieu concentrates on status competition.

As well as the hierarchical structure between high culture and popular culture, in the field of fashion there are two opposite sides when it comes to the name of designers. According to Bourdieu (1993: p. 160), on the left are the ones considered new designers, such as Paco Rabanne and Ungaro; on the right are the old consecrated couturiers such as Balmain and Dior. That is, whereas Balmain and Dior are located on Paris's right bank-the old bourgeois area-Rabanne and Ungaro are on the left bank-the avant-garde bank. The old consecrated "couturiers" are structurally adjusted to the old bourgeoisie, whereas the new designers are structurally adjusted to the new bourgeoisie.

There is a similar homologous relationship between classes of products and 
classes of consumers (Bourdieu, 1975: pp. 32-33). It is precisely because a cultural object is the objectification of the already "constituted taste" of the producer (Bourdieu, 1996: p. 231). When a cultural production is addressed and limited to a restricted audience as high culture is, the main profit is the art itself. On the contrary, high fashion that is produced in a large-scale in favor of a wide audience, the profit is merely financial. This market is usually referred as mass culture or popular culture.

There are many cases in the field of contemporary fashion where high fashion and popular fashion are intricately related. As Elzingre (1996: p. 46) argues, if luxury fashion in its early days was the concern of a narrow public, it has become increasingly addressed to a wide market. Consuming high fashion does not consist solely of buying high-fashion clothes, but also concerns consuming images of luxury fashion, to the point where high fashion has become "an art which carries along popular fervor". The transgression of the boundary between high fashion and popular fashion quickly attracted many couturiers (Grumbach, 1993), and led Bourdieu to review his theoretical framework. Had Bourdieu registered the rise of mass fashion and the blurring of the boundaries between high fashion and mass fashion, there is no reason to believe that this would have led him to question the overall structure of his sociological system.

Fashion designers do transgress the line between high fashion and mass fashion. They do move between the fields of fashion, as they are not ascribed to one specific position or role. As stated before, the prestige of haute couture is under the name of the designers. The value of a brand is the brand itself, it is a symbolic value, regardless whether the brand is a product of haute couture or commercialized to a mass market. That having been said the paper will explore how Balenciaga brand, traditional in the luxury fashion market, has been showing important changes in its strategy in the digital environment during the last few years, specifically on its Instagram profile, an important platforms of communication and reproduction.

\section{Methodology}

The methodology of this article is divided into two parts. The first research method used to build the theoretical discussion was through bibliographical research, which is based on materials already published. According to Gil (2010), this method of research includes printed materials, such as books, magazines, journals, thesis, dissertations and congress papers. Furthermore, due to dissemination of technology, the bibliographical research also started to consider other resources gathered from the Internet.

The theoretical discussion involved the central themes of this article such as popular culture, mass culture and haute couture in order to support the second part of the paper, which was a case study about Balenciaga brand.

The case study considered an in depth analysis about Balenciaga's campaigns on the Instagram platform, in which the goal was to understand their expressiveness and the brand disruptive approach to their audience (mainly youngers), 
breaking the barrier between high fashion and popular fashion, but still maintaining its status of being a luxury brand (Nepomuceno, 2019).

\section{The Balenciaga Case}

Balenciaga was founded by the late couture designer Cristobal Balenciaga. In order to understand him, it only needs to study his designs. Using minimal ornamentation, his garments were simple, impeccably cut and completely harmonious in line and shape. Balenciaga was a designer dedicated not only to the art of design, but to his small staff of employees and to the country whose rich culture influenced the fabrics, colors and details of his garments. Balenciaga's garments were designed to flatter almost any female form, creating slenderness, height and graceful movement even where there was none (Pennington, 1995). Through his designs, he attempted to draw attention to the women he clothed. He designed for a select few loyal clients transforming them into an elegant noble.

Balenciaga was born January 21, 1895 in Guetaria, Spain. He lived a humble life with his mother and two siblings. His father, a sailor and mayor of the village, died at an early age. To support her family, Balenciaga's mother became a seamstress and taught dressmaking to village girls. She was young Cristobal's first inspiration.

By 1919, he opened his first design house in San Sebastian. San Sebastian was a fashionable resort where the Spanish royal family often vacationed. Subsequently, Balenciaga's first commission was a wedding gown designed for a royal wedding, giving him the opportunity to meet Queen Victoria Eugenia and the Queen Mother Maria Cristina. So impressed they were with his dresses, both became clients of this young, unknown designer. This was the launching point of Balenciaga's fame.

Balenciaga had the reputation of being a stylist without any commitment with certain standards and conventions. He was a free artist and a daring creative, and was referred to by Christian Dior as "the master of us all". Although Balenciaga's collections were attractive and well received by the public, the early 1960s marked the beginning of Balenciaga's decline. This is because pret a porter, or ready to wear clothing was the tendency of the fashion market. As a well known haute couture designer, Balenciaga could have made a fortune launching pret a porter lines. However, when new designers, such as Yves Saint Laurent, appeared on the fashion scene with the pop music as the new inspiration and launching pret a porter lines, Balenciaga turned his back to it stating, "I shall never prostitute my art" (Jouve, 1989). While designers such as Dior, Saint Laurent and Courreges licensed their designs and built empires by banking their names, Balenciaga continued his business as usual.

Every garment bearing the Balenciaga name had been touched by the designer until his death in 1972. His last creation, like the first commission from 1919, was a royal wedding dress for a former client's daughter, the Duquesa de Cadiz. 
When he died, the last vestige of true haute couture died with him.

Although some of his greatest creations were scoffed at by the media when Balenciaga unveiled them, the world of fashion has now come to appreciate the brilliance and beauty Cristobal Balenciaga offered.

Today, Balenciaga is owned by the French luxury group Kering and has as creative director Demna Gvasalia who is revamping Balenciaga, and unlike the creative directors of traditional luxury brands, he is inspired by the unusual in this renewal of brand. Through digital channels (mainly Youtube and Instagram), he is redefining luxury.

Since Demna Gvasalia took over the creative direction of Balenciaga, the image of the brand as a whole has been completely reinvented. A quick look at its Instagram proves this change. Considered crazy and bizarre by many people, Balenciaga's social networks are the opposite of what you would expect from a luxury brand. The company does not promote the image of perfection, and uses beauty standards that we are not used to seeing within the fashion world. The photos are of low quality and taken in an amateur way, for example. The posts do not follow a logical reasoning, and do not even have captions, hashtags, or identification of the products displayed (Figure 1).

For two years, Balenciaga has been standing out in the market, especially among young people. According to Balenciaga CEO Cedric Charbit during an interview to Reuters in 2018, "Millennials" are largely responsible for the growth of the brand: "Millennials represent 60 percent of what we sell. Together with men, these are growing faster than any other [category]" (Reuters, 2018).

This impressive growth of the brand is due to several factors, but mainly due to thousands of young people of the "Millennial" generation (who now represent one third of the global luxury goods market) who believe in the designer's luxurious vision of street wear, which is communicated and escalated through social networks.

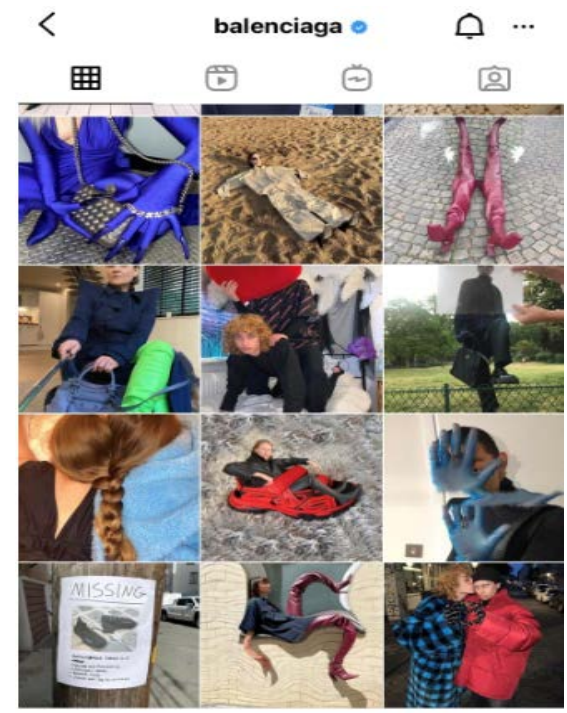

Figure 1. Balenciaga (2020)'s Instagram profile. Retrieved from Instagram https://www.instagram.com/balenciaga/. 
While the luxury market in general has the challenge of dealing with a target audience which is getting older, Balenciaga is being successful in reaching younger generations.

It is clear that Instagram takes the lead in the brand's communication strategy, since it is the platform capable of reaching younger audiences and increasing sales. During 2020, even with the Covid-19 pandemic crisis, the brand gained an average of $382 \mathrm{~K}$ new followers and this number started to grow exponentially (Figure 2).

Another disruptive approach of Balenciaga is the heavy investment in in products with a meme-baiting look (products that go viral because they are "controversial"). An example (Figure 3) is its purse inspired by Ikea shopping bags (a bag originally for a few cents, but which at Balenciaga costs more than thousands of Euros). As per OMR (2018) website, Demna commented on the strategy: "I used the blue Ikea bag during my four years as a student in Antwerp, due to its size and price. I wanted to do this as an ironic gesture, taking something really cheap and moving it into the realm of luxury. But it's authentic too, which is why it's going viral over the internet. People can identify themselves".

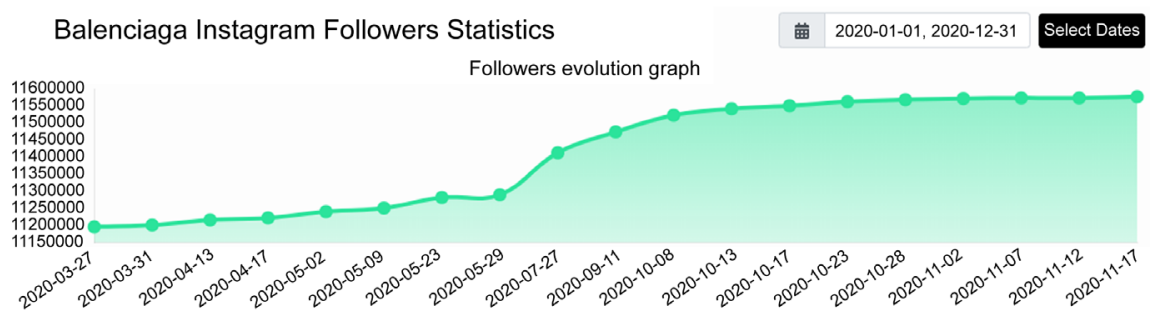

Figure 2. Balenciaga instagram followers statistics. Retrieved from Speakrj (2020). https://www.speakrj.com/audit/report/balenciaga/instagram/2020-01-01/2020-12-31.

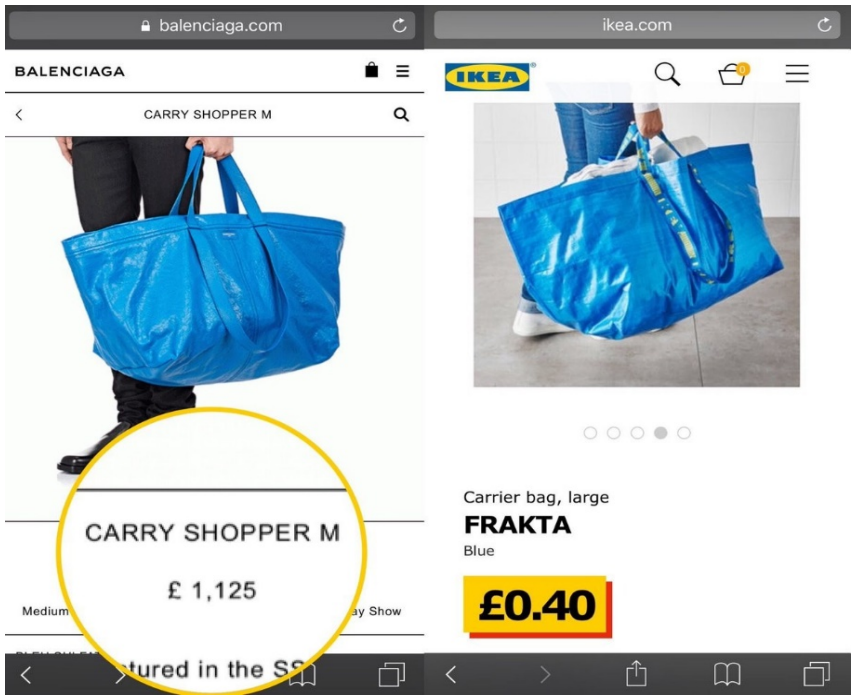

Figure 3. Balenciaga bag vs. Ikea bag. Retrieved from Imaginação Fértil (2017) https://www.imaginacaofertil.com.br/bolsa-ikea-by-balenciaga/. 
With this tight relationship that permeates irony and authenticity, the designer managed to expand his audience. Consumers can interpret garments as signs of protest, irony, authenticity, or even decay (LinkedIn, 2019). For certain customers, paying dearly for using popular symbols (like shopping bags) make products especially attractive. In addition, Balenciaga is betting on the campaign that "Ugly is the new black", in contrast to his predecessor Alexander Wang, known for elegant and tasteful designs, Gvasalia stands out for investing in flashy colors, atypical patterns, and an exaggeration in the display of logos.

As the strategy was working at Balenciaga, in 2017 Demna Gvasalia continued it. The brand deepened the "meme-bait" strategy for other accessories, when parading shoes in partnership with the Crocs brand. Once again, the brand turned a symbol of mass consumption culture into a luxury item.

\section{Final Considerations}

Balenciaga is of a careful and deep analysis regarding the brand positioning within the luxury market in response to a set of behavioral trends. There is an increasing concern with various themes related to the stigma of beauty, status, self-esteem, etc. The brand scoffs and questions the clichés that surround the fashion industry and its followers. There is a sense of imperfection and authenticity, in which the Generation Z, the so-called digital natives, relate. Coincidence or not, this audience today accounts for more than $60 \%$ of the company's sales.

Most of these young people are looking for something that makes them stand out and feel special, which goes beyond an incredible and elegant finish, characteristic of other traditional brands. This may not be the public that would invest $€ 5.000$ on a jacket, but they do not mind buying a $€ 450$ t-shirt or $€ 600$ sneakers, resulting in higher margins and sales volume.

If we look at the company's communication before this change, we will see that it was in no way different from others in the fashion world. The focus is on the products, luxury, status, standard, and the obvious. Balenciaga saw an opportunity to reinvent its brand, bringing innovation in its positioning.

Today, Balenciaga builds individuality through its positioning. Their success in digital platforms especially on Instagram is the consequence of a creative concept that starts with the product. A unique creative concept, which celebrates and provokes the denial of luxury (anti-luxury) in contemporary times, attributes to the product itself the self-promotion ability mainly in the digital environment.

By mocking the fashion industry through the irreverence of raising symbols of mass consumption, Demna Gvsalia creates viral potential in his own creations, making the product itself a piece communication. A creative provocation that launches trends and guides the conversation on and off social media dividing opinions in the fashion world.

Demna Gvsalia is responsible for introducing part of the digital language in haute couture, and for introducing the meme into fashion. The fact is that the movement of differentiation of Balenciaga in the fashion world by applying the 
"meme-baiting" strategy to products reversed the standards in the luxury market and as a result promoted excellent quantitative results. However, the concern is whether the meme-baiting will remain or not. Will it dissipate and force Balenciaga to find a new way to stay relevant? We can't actually respond to these questions, but it is possible to confirm that Demna Gvasalia's ostentatious and tireless search for imperfection led the brand to achieve its current success among its audience. Therefore, it would be extremely recommendable if these questions could be responded through further research techniques, such as content analysis to measure Balenciaga's relevance statistics and focus groups in order to get responses from a group of people who consume Balenciaga's products and follow the brand profiles on social media.

\section{Conflicts of Interest}

The author declares no conflicts of interest regarding the publication of this paper.

\section{References}

Balenciaga (2020). Balenciaga's Instagram Profile. https://www.instagram.com/balenciaga/

Bourdieu, P. (1975) (with Y. Delsaut) Le Couturier et sa Griffe. Contribution à une Théorie de la Magie. Actes de la Recherche en Sciences Sociales, 1, 7-36.

Bourdieu, P. (1993) La Misère du Monde. Paris: Seuil.

Bourdieu, P. (1996) Distinction: A Social Critique of the Judgement of Taste. London: Harvard University Press.

Chris, B., \& Jane, E. (2016). Cultural Studies: Theory and Practice. London: Sage.

Douglas, M., \& Isherwood, B. (1996) The World of Goods. London: Routledge

Eliot, T. S. (1948). Notes towards the Definition of Culture. London: Faber \& Faber.

Elzingre, M. (1996) Femmes Habillées. Paris: Austral.

Fiedler, L (1955). The Middle against Both Ends. In L. A. Fiedler (Ed.), Mass Culture (pp. 539-540). London: Martin Secker \& Warburg, Ltd.

Gil, A. C. (2010). Como elaborar projetos de pesquisa (5th ed.). São Paulo: Atlas.

Grumbach, D. (1993) Histoires de la Mode. Paris: Seuil

Hobsbawm, E. (2000). The New Century. London: Little, Brown

Hobsbawm, E. (2013). Fractured Times. Culture and Society in the Twentieth Century. London: Little, Brown

Imaginação Fértil (2017). Bolsa da IKEA by Balenciaga. https://elpais.com/elpais/2017/04/19/estilo/1492594133_329816.html

Jouve, M.-A. (1989). Cristobal Balenciaga. Translation from French. New York, NY: Rizzoli

Leavis, F., \& Thompson, D. (1933). Culture and Environment: The Training of Critical Awareness. London: Chatto \& Windus

LinkedIn (2019): BALENCIAGA: Como uma empresa antiquada tornou-se "The hottest Brand in the World", e o que isso tem a ver com inovação?

https://www.linkedin.com/pulse/balenciaga-como-uma-empresa-antiquada-tornou-se- 
brand-alexandre/?originalSubdomain $=\mathrm{pt}$

Macdonald, D. (1953). A Theory of Mass Culture. Diogenes, 1, 1-17.

Nepomuceno, M. D. (2019). Construção da marca Balenciaga nas das redes sociais: um estudo no Instagram. (Monografia de Pós-Graduação). São Paulo: Departamento de Relações Públicas, Propaganda e Turismo da Escola de Comunicações e Artes da Universidade de São Paulo.

OMR (2018). https://omr.com/en/balenciaga-meme-baiting/

Pennington, T. L. (1995) Cristobal Balenciaga: The Legend of Fashion's Last Haute Couturier Revealed. Indiana: Ball State University

Reuters (2018). Men and Millennials Propel Sales Boom at Kering's Balenciaga. https://www.reuters.com/article/uk-balenciaga-kering-sales/men-and-millennials-prop el-sales-boom-at-kerings-balenciaga-idUKKCN1IN2SD

Shils, E (1978). Mass Society and Its Culture. In P. Davison, R. Meyersohn \& E. Shils (Eds.), Literary Taste, Culture and Mass Communication (Vol. 1, pp. 35). Cambridge: Chadwyck Healey.

Speakrj (2020). Balenciaga Instagram Followers Statistics.

https://www.speakrj.com/audit/report/balenciaga/instagram/2020-01-01/2020-12-31

Storey, J (1997). Cultural Theory and Popular Culture: An Introduction. London: Prentice Hall.

Svendsen, L. (2006). Fashion: A Philosophy. London: Reaktion Books.

Van Den Haag, E (1963). Passion and Social Constraint. New York, NY: Stein and Day

Williams, R. (1975). The Long Revolution. Harmondsworth: Penguin Books. 